\title{
The Carboneras Fault Zone (southeastern Spain) revisited with Ground Penetrating Radar - Quaternary structural styles from high-resolution images
}

\author{
K.R. Reicherter ${ }^{1,2} \&$ S. Reiss ${ }^{1}$ \\ ${ }^{1}$ Neotectonic Research Group, Geologisch-Paläontologisches Institut, Universität \\ Hamburg, Bundesstraße 55, D-20146 Hamburg, Germany \\ 2 corresponding author; e-mail: reicherter@geowiss.uni-hamburg.de
}

Manuscript received: July 2000; accepted: April 2001

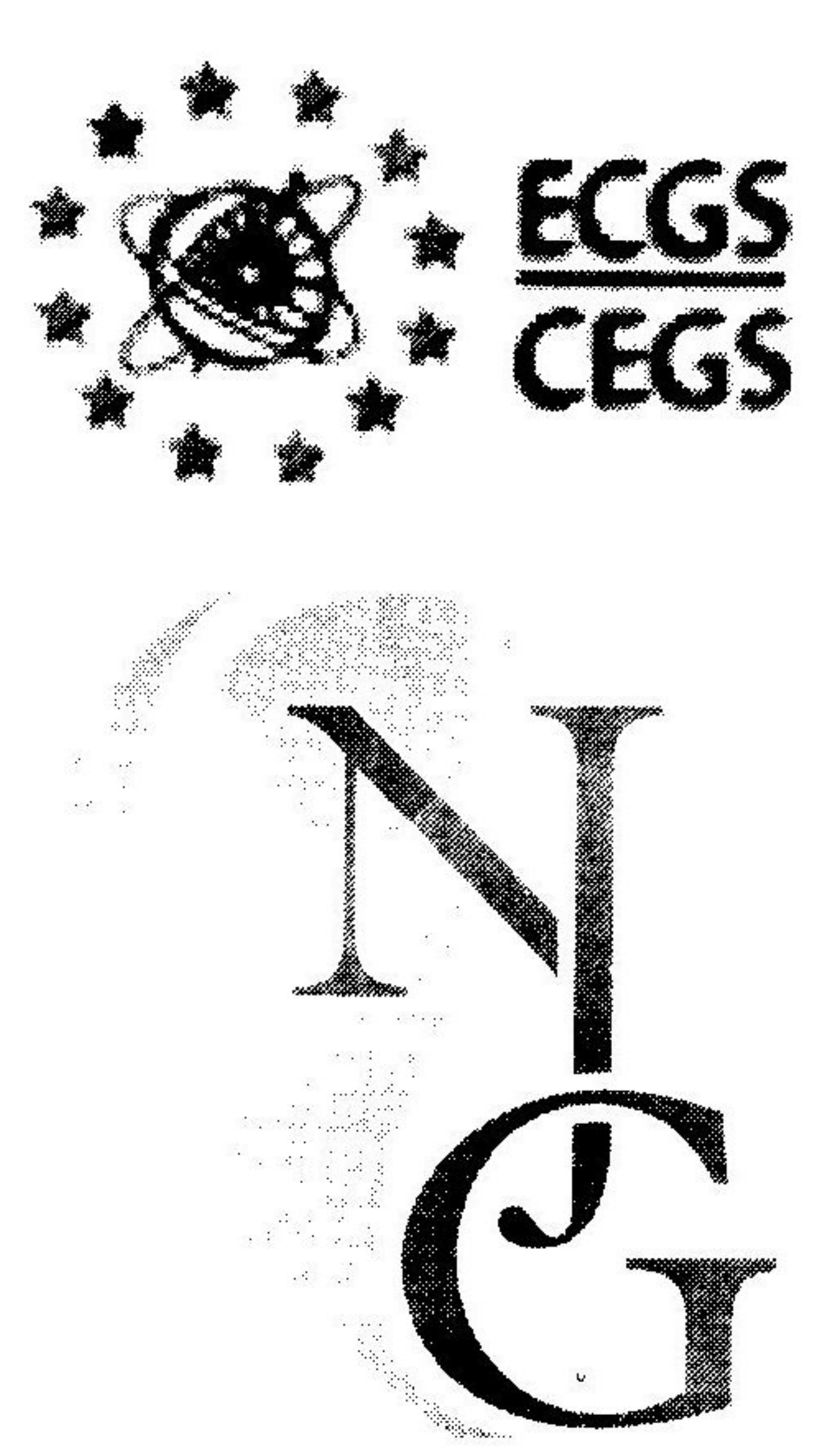

\begin{abstract}
The Carboneras Fault Zone (CFZ) represents an active set of sinistral strike-slip faults in the Betic Cordilleras of southeastern Spain. It constitutes a major segment of the 'Trans-Alboran shear zone' during the Cenozoic, striking NE-SW. The CFZ separates the Cabo de Gata Block (Neogene volcanics) against Neogene basinal sediments and the metamorphic basement of the Alpujarride Complex.

Three sites along the CFZ were examined with Ground Penetrating Radar techniques. Radar surveying was complemented by structural studies. Shallow-depth high-resolution imaging of Tyrrhenian beach terraces exhibited both vertical and minor horizontal offsets in the Rambla Morales site in the south. A sinistral strike-slip fault associated with minor thrust faults in a positive flower structure was detected in the middle segment along the La Serrata ridge, sealed by a caliche of late Pleistocene age ( $>10 \mathrm{ka}$ ). The Playa de Bolmayor section yielded sub-surface evidence for several faults probably related to recent activity of individual fault strands. Our results suggest a distributed tectonic activity of the CFZ during the Late Quaternary.
\end{abstract}

Keywords: Ground Penetrating Radar, paleostress analysis, paleoseismology, Betic Cordilleras.

\section{Introduction}

During the past two decades, numerous studies were dedicated to the Neogene geological and structural evolution of southeastern Spain, which represents a region in the Betic Cordilleras characterized by to complex strike-slip fault systems, Neogene volcanism and sedimentology.

The Carboneras Fault Zone (CFZ) represents a major sinistral strike-slip fault in the Betic Cordilleras of southeastern Spain (Fig. 1 and 2) accompanied with pressure ridges and pull-apart basins (e.g., Boorsma, 1992, 1993). The onshore segment of about $50 \mathrm{~km}$ length of the 'Trans-Alboran shear zone' of Montenat \& Ott D'Estevou (1995) is striking approx. NE-SW, and partly anastomosing in E-W striking minor faults. Neogene slip along the fault may be distributed during approx. $10 \mathrm{ma}$ of NW $-\mathrm{SE}$ and subsequent N-S shortening, with important influence on the tectono-stratigraphic evolution of the Betics (Sanz de Galdeano, 1990; Montenat \& Ott D'Estevou, 1995; Martin \& Braga, 1995). Since the Tortonian about $30 \mathrm{~km}$ horizontal slip occurred along the individual faults, placing Neogene volcanics of the Sierra de Gata against the metamorphic basement of the Betics and syn-tectonic sediments (Montenat \& Ott D'Estevou, 1995). The northeastern termination branches into the sinistral NNE-SSW trending Palomares Fault, which on the other hand is connected with and related to the Ramonete Fault Zone (Fig. 1). The southwestern continuation of the CFZ prolongates offshore into the Gulf of Almería. The CFZ displaces the Cabo de Gata Block (Neogene volcanics) against Neogene basinal sediments and the 


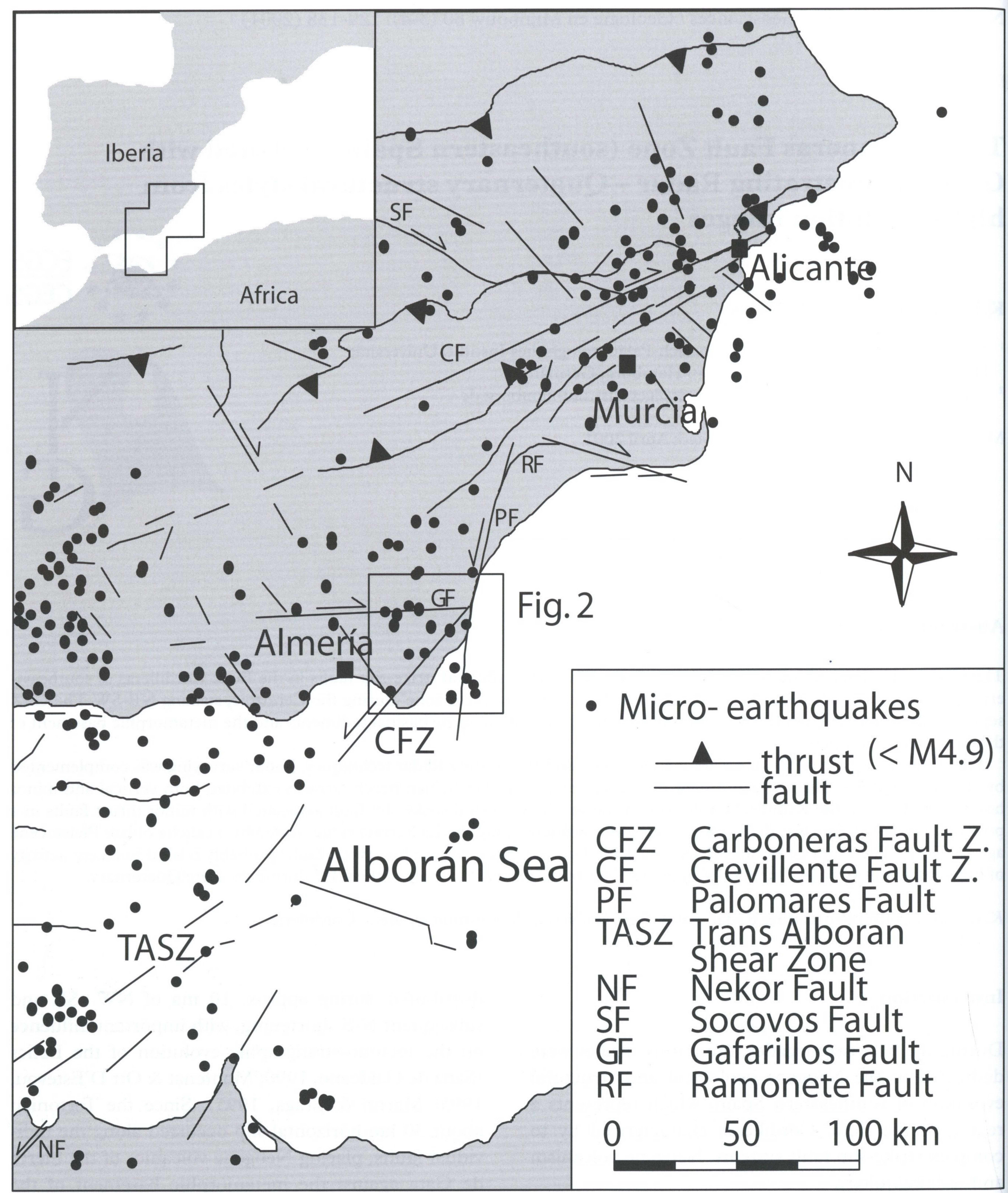

Fig.1: Map of the investigated area in southern Spain displaying the main structural features. Dots mark instrumental earthquakefoci $(M<$ 4,9 between 1990-2000, data selection from www.ign.es; www.ugr.es/iag; www.ua.es/ursua), note apparent accumulation along the Crevillente Fault Zone west of Alicante and around the Granada Basin (west of Almería).

metamorphic basement of the Alpujarride Complex and the Nevado-Filabride Complex along individual northern fault strands (Fig. 2).

The Carboneras Fault Zone has been divided into several minor faults named Almeria Fault or Serrata
Fault along the La Serrata ridge, Sopalmo and Colorados Faults in the northeastern part around Carboneras (Keller et al., 1995). The sinistral transpressional fault zone forms a characteristic flower structure involving Neogene volcanics, Messinian gypsum 


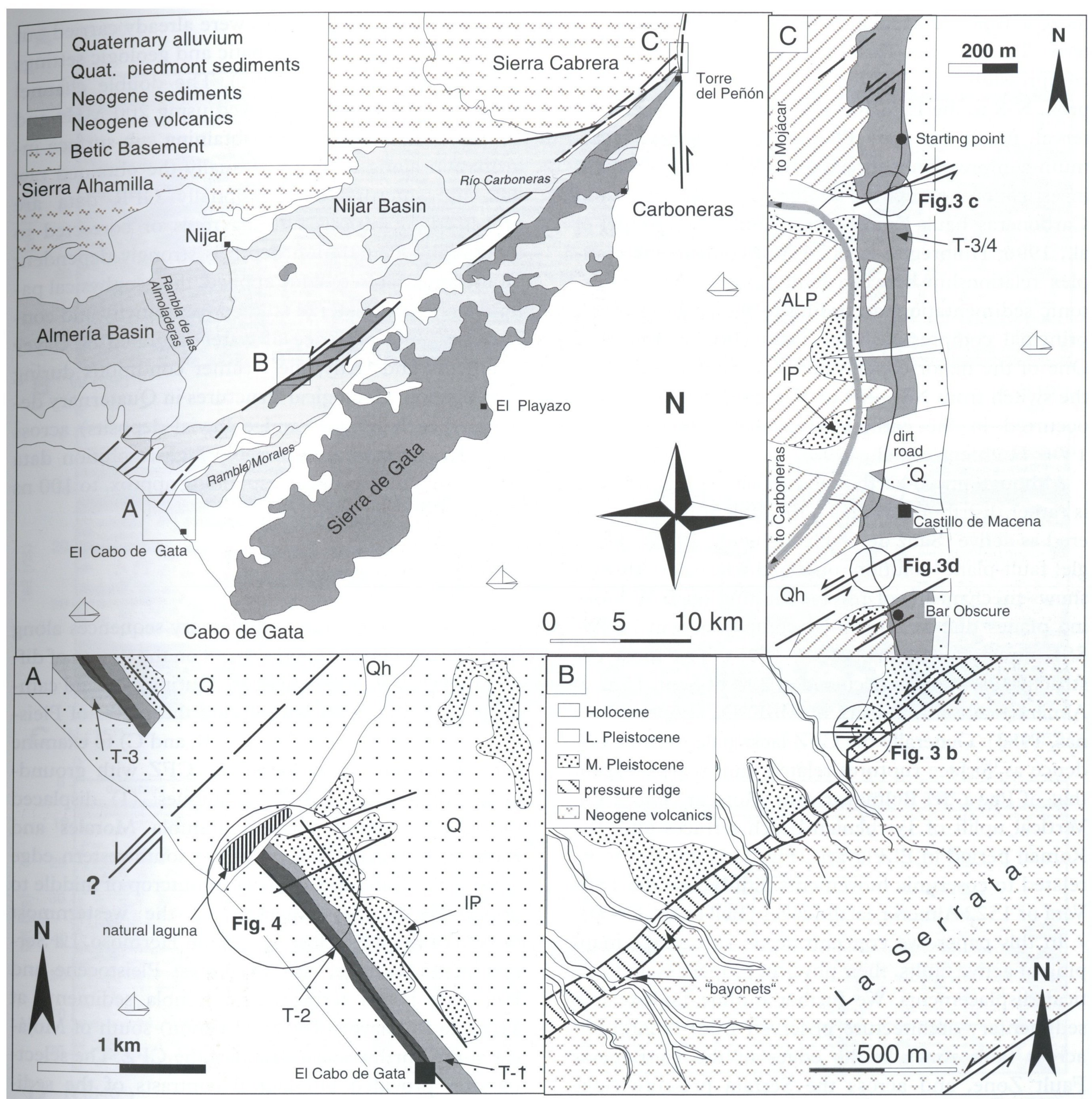

Fig. 2: Simplified geological overview of the Carboneras Fault Zone and the Cabo de Gata region. Small Neogene basins within the Cabo de Gata Block have been left, encircled areas in detail maps show radar survey sites. Fig. 2A: Simplified geological map of the Rambla Morales site (modified from geological map No. 1059 and Zazo et al., 1998); $\mathbb{P}=$ lower Pleistocene beach terraces; T- $1=$ Tyrrhenian I marine terraces, T-2 = Tyrrhenian II marine terraces, T-3 = Tyrrhenian III marine terrace, $Q=$ undifferentiated Holocene, and $\mathrm{Qh}=$ recent alluvial sediments . Fig. 2B: Simplified geological map of the La Serrata site near Campo Hermoso, note left-lateral displaced creeks (bayonets, modified after Bell et al., 1997). Fig. 2C: Simplified geological map of the Playa del Bolmayor (modified from geological map No. 1031 and own mapping) ALP $=$ Alpujárride Complex, $\mathbb{P}=$ lower Pleistocene terraces; $\mathrm{T}-3 / 4=$ Tyrrhenian III and IV marine terraces, $\mathrm{Q}=$ undifferentiated Holocene, and $\mathrm{Qh}=$ recent alluvial sediments.

and Messinian marls (Keller et al., 1995, 1997). Individual fault-bounded blocks are relatively unstrained and aligned in Y-shaped shear lenses, connecting NESW trending structures with E-W oriented faults. The Neogene faulting history and paleostress analyses have dominantly been studied by Dutch geologists (e.g., Biermann, 1995; Stapel et al., 1996; Huibregtse et al., 1998) and French working groups (e.g., Mon- tenat \& Ott d'Estevou, 1995). The kinematic evolution of the CFZ according to Keller et al. (1997), as preserved in Neogene sediments, states a NE-SW compressional stage during the Burdigalian and Early Langhian and a switch to a stable NNW-SSE compression from the Serravallian to Recent. These results contradict studies of Biermann (1995) and Montenat and Ott d'Estevou (1995), who draw a 
more complex Tortonian to Recent deformation pattern. During the Tortonian horizontal maximum compression was directed NW-SE, switching to approx. N-S in the Late Tortonian to Early Pliocene interval, finally the Late Pliocene to Holocene maximum compression is directed NNW-SSE. Paleostress investigations along the Gafarillos, Palomares and Carboneras Fault Zones (Biermann, 1995; Stapel et al., 1996; Huibregtse et al., 1998) confirm the complex relationship between fault activity and syn-tectonic sedimentation, according to the rotation of the principal compressive stress axes (Boorsma, 1993). One of the major conclusions is a refined timing for the switch from NW -SE to N-S compression, which occurred in the earliest Messinian (Stapel et al., 1996; Huibregtse et al., 1998).

Although micro-earthquake activity along the CFZ is rather distributed (Fig. 1), the fault zone is considered as active (Sanz de Galdeano et al., 1995). A single fault-plane solution obtained close to Almería shows mechanisms of reverse faulting on E-W striking planes due to horizontal compression in NNWSSE direction (Buforn et al., 1995). The most destructive earthquake occurred at $22^{\text {nd }}$ of Sept. 1522 in Almeria with an intensity of MSK IX (López Marinas, 1983). Generally the CFZ lacks paleoseismic evidence as surface ruptures related fault scarps, except that of Playa del Bolmayor near Mojácar (Fig. 2 C). Vertical uplift of Tyrrhenian beach terraces after the Roman period in El Playazo (Fig. 1) is thought to be related to coseismic movements induced by the 1518 Vera or 1522 Almeria earthquakes (Bell et al., 1997).

In this paper, we concentrate on subsurface mapping of active faults, their physical properties and vertical displacements. We further outline fault-related sedimentary architecture observed from radargrams across fault zones at the edges of the Carboneras Fault Zone, and across the Serrata pressure ridge (Fig.2) in order to study the relative age of the faulting events.

\section{High-resolution Ground Penetrating Radar Profiling}

\section{Method}

The Ground Penetrating Radar (GPR) technique is a geophysical standard tool in paleoseismological investigations applied, e.g., in pre-trenching studies. Depending on the geological setting, GPR surveys are non-intrusive, rapid and reliable for effective mapping of shallow subsurface sediments, hydrologic conditions, and potential geologic hazards (e.g., active faults). Neotectonic and paleoseismic investigations combined with GPR studies were already carried out successfully in different climatic and geologic settings (e.g., Meschede et al., 1997). The double channel SIR-10 B system was employed using $200 \mathrm{MHz}$ and $400 \mathrm{MHz}$ antenna sets for obtaining sub-surface information along the CFZ. Usually the obtained raw data are interpreted, occasionally GPR data are processed by various filtering tools or corrected to topography. Penetration depth is strongly dependent on the antenna frequency applied, the geophysical parameters of the material studied (permitivity and conductivity), the presence of water-saturated or clayey sediments and lastly, the weather conditions during investigation. Geological structures in Quaternary deposits (beach terraces and colluvial deposits) across the CFZ revealed interpretable high-resolution data sets up to $5 \mathrm{~m}$ depth, corresponding approx. to $100 \mathrm{~ns}$ TWT (two way traveltime).

\section{Results and Interpretation}

Neogene to Quaternary sedimentary sequences along the fault zone offer a good control on the timing of dif-', ferent phases of fault activation. During our field campaign in spring 2000, we selected three sites of Pleistocene - Holocene age (Fig. 2A, B, and C) to examine sub-surface structures along the $\mathrm{CFZ}$ with groundpenetrating radar (GPR) techniques: (1) displaced Quaternary marine terraces Rambla Morales and Rambla de las Amoladeras at the southwestern edge close to the Cabo de Gata, (2) an outcrop of middle to upper Pleistocene sequences of the westernmost branch of the CFZ close to Campo Hermoso, La Serrata pressure ridge, and (3) Latest Pleistocene and Holocene beach terraces and rambla sediments at Playa de Bolmayor (Torre del Peñon) south of Mojácar at the northwestern strand of the CFZ. The selected sites provided lithological contrasts of the sediments, i.e. sand vs cemented conglomeratic terraces or coarse-grained rambla sediments vs beach sands

\section{1) Rambla Morales site ( $\left.N 36^{\circ} 47^{\prime} 740, W 2^{\circ} 15^{\prime} 430\right)$}

The Rambla Morales is located at the southwestern edge of the CFZ (Fig.2A) close to the village of Cabo de Gata, where the CFZ passes off the Gulf of Almeria. The trace of the CFZ is not outcropping. However uplifted Tyrrhenian marine terraces (Tyrrhenian I-III, $180 \mathrm{ka}$ to $95 \mathrm{ka}$, after Hillaire-Marcel et al., 1986) are smoothly tilted towards SW and are also dissected by associated NW-SE striking normal faults. The estuary of the Rio Morales is naturally dammed accompanied with the seasonal development of a laguna, probably due to active tilting of the terraces along the normal faults (Fig. 4A). 


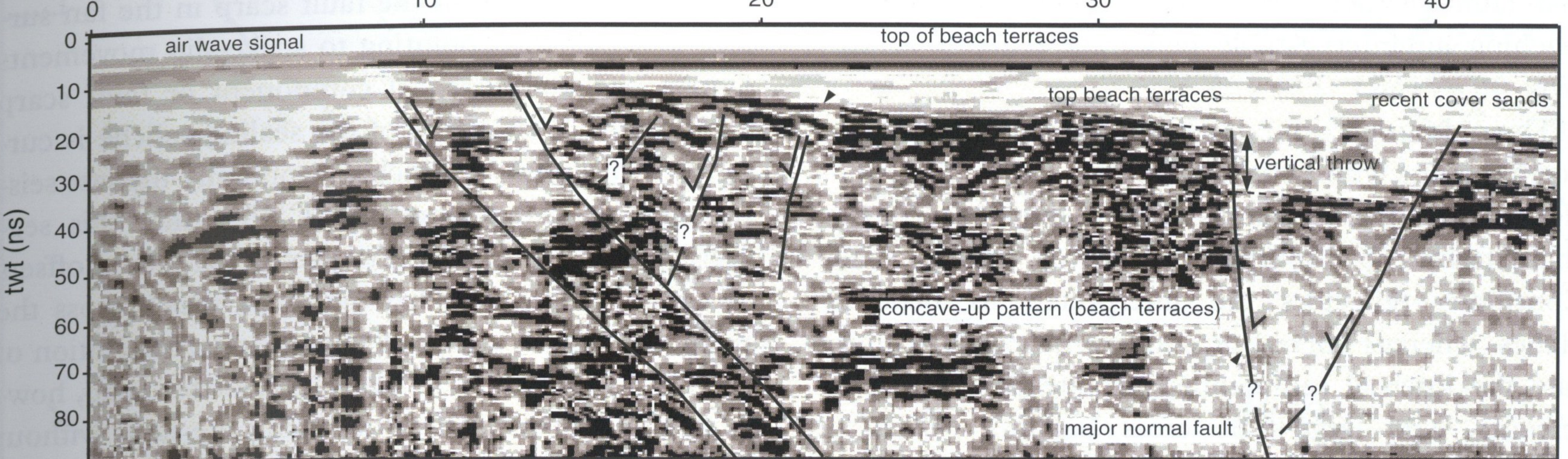

B $\mathrm{W}\left(290^{\circ}\right)$

distance $(m) \longleftarrow$ sketch area in Fig. 5

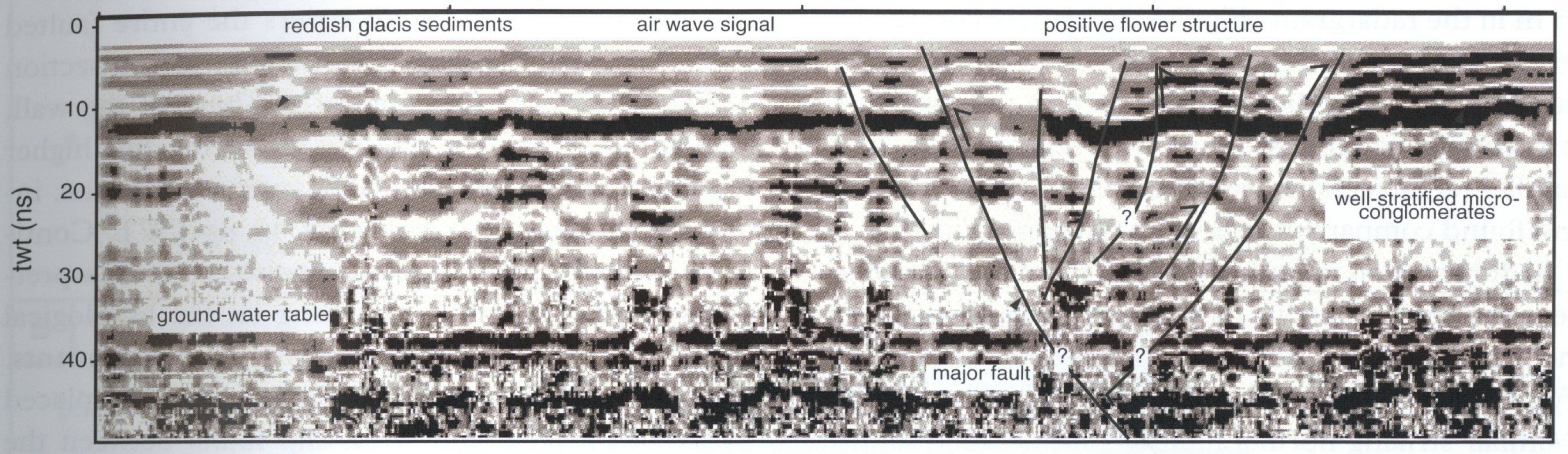

C $\mathrm{N}\left(15^{\circ}\right)$

distance $(\mathrm{m})$

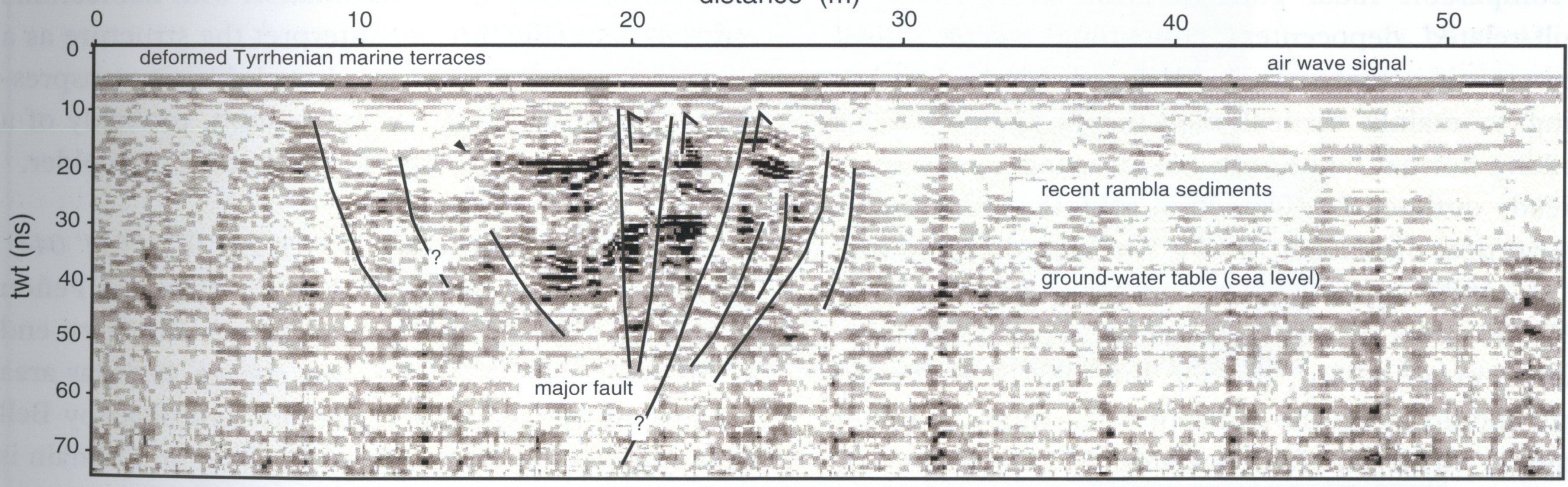

D $\mathrm{N}\left(340^{\circ}\right)$

distance $(m)$

$\mathrm{S}\left(160^{\circ}\right)$

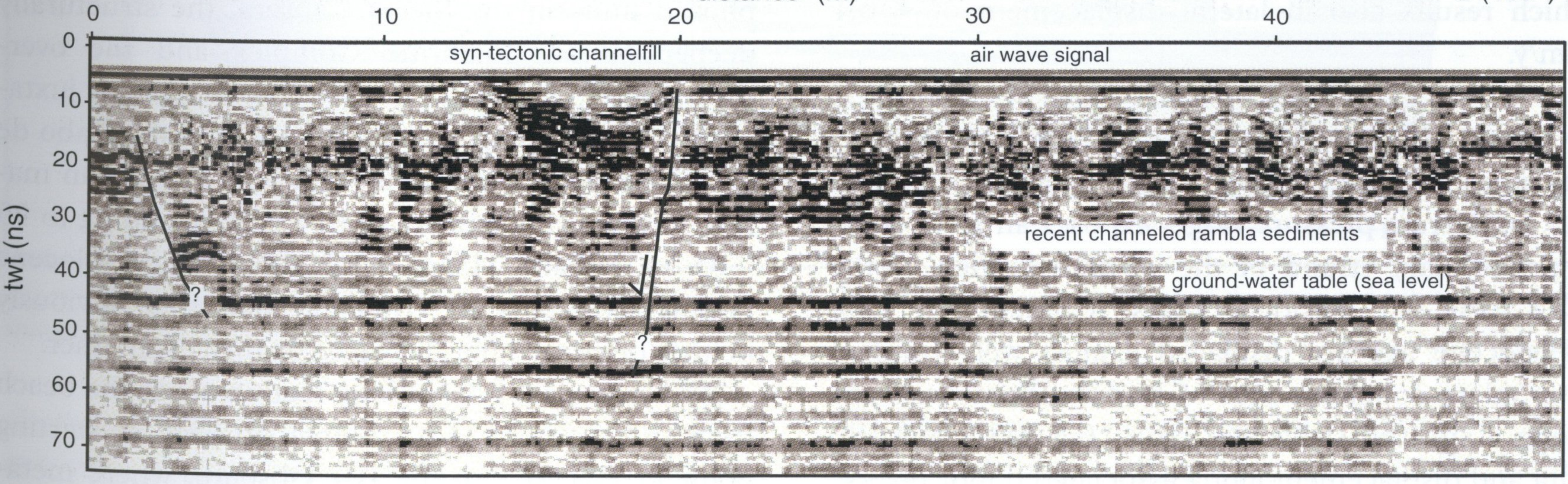

Fig. 3: Radargrams and interpretation (all $400 \mathrm{MHz}$ antenna, except (A) $200 \mathrm{MHz}$ antenna), orientation of the radargrams at the top of the figures. (A) perpendicular section to active NW-SE striking normal faults (location see Fig. 2A); (B) positive flower structure along W-E striking, secondary sinistral strike-slip faults (location see Fig. 2B, outcrop log and fault-slip data see Fig. 4A); (C) active NE-SW striking strikeslip faults associated with a positive flower structure in displaced Tyrrhenian terraces (location see Fig. 2C); (D) active NE-SW striking transtensional faults with syn-tectonically subsiding asymmetric channel (location see Fig. 2C). 
With the $200 \mathrm{MHz}$-antenna, we surveyed the normal fault geometry in a $45 \mathrm{~m}$ long GPR section reaching an interpretable penetration depth of approx. 90 ns TWT (Fig. 3A).

The radargram exhibits several high- and low-angle normal faults with antithetic normal faults. The individual fault planes and associated minor faults are characterized by continous reflector terminations. Continous reflectors are interpreted as bedding planes, whereas curved or concave-up patterns indicate the internal sedimentary architecture of beach terraces, e.g., large-scale cross bedding or channelfills. The top of the terraces and the dip of the surface towards SW are obvious. The major fault around $33 \mathrm{~m}$ in the radargram (Fig. 3A) is entirely covered by recent sands. The hanging wall of the major fault shows a change in the intensity pattern pointing to a syn-tectonic halfgraben filling with recent sands. In 9 parallel radar sections we were able to trace the fault and found comparable reflection patterns (Fig. 4B).

Sedimentation in fault-depending and fault-created depocenters testifies to recent tectonic activity along the normal fault. In a radar section across the Tyrrhenian-2 terrace (Fig. 4A), which is seperated by a similar striking normal fault to recent beach sands, a comparable radar pattern. From the creation of fault-related depocenters containing recent sands, neotectonic activity may be deduced. However, testifying to mainly vertical movements along NW-SE striking normal faults with SW-directed extension as already outlined by Zazo et al. (1998). According to the vertical displacement of $>5 \mathrm{~m}$ (according to Bell et al., 1997 approx. $10^{-} \mathrm{m}$ ) and the age of approx. 128.000 years of the Tyrrhenian-2 terrace (HillaireMarcel et al., 1986), the slip rate on the particular fault should be on the order of $<0,1 \mathrm{~mm} / \mathrm{y}$. A minor sinistral strike-slip fault striking $75^{\circ}$ displaces late pre-Tyrrhenian Pleistocene terraces about $38 \mathrm{~m}$, which results also in lateral displacement of $<0,1$ $\mathrm{mm} / \mathrm{y}$.

\section{2) Campo Hermoso site ( $\left.\mathrm{N} 36^{\circ} 55^{\prime} 613, \mathrm{~W} 2^{\circ} 05^{\prime} 191\right)$}

An outcrop located close to Campo Hermoso along the La Serrata pressure ridge, exposes an E-W striking secondary strand of the western branch of the CFZ (Fig.2B). Reddish glacis sediments of Late Pleistocene age are displaced against well-stratified grey micro-conglomerates of Middle Pleistocene age along a sinistral strike slip fault (Fig.5A). Fault-slip data and displacement along associated minor reverse faults suggest a transpressive regime.

A brecciated, partly nodular caliche seals the fault directly below the recent soil, which probably developed during late Pleistocene above an abandoned sta- ble fan surface (Alonso-Zarza et al., 1998). No geomorphic expression of the fault scarp in the fan surface is observable, pointing to strike-slip movements with a negligible vertical component or fault scarp degradation. The dating of the sealing caliche is currently in progress to bracket temporally the last seismo-tectonic event along the CFZ within this segment. Bell et al. (1997) interpreted left-lateral offsets of small creeks, so-called bayonets, which cross the pressure ridge as a sign of Quaternary reactivation of the CFZ (Fig. 2B). The geological sketch map, however, shows several creeks crossing the fault without being displaced. The age of the displacement was estimated to be older than $100 \mathrm{ka}$ (Bell et al., 1997).

A profile of $41 \mathrm{~m}$ length covers the entire faulted zone (Fig. 3B) including the studied outcrop section of Fig.5A along a dirt road at the base of the wall. Due to application of the less powerful, but higher resolution supplying $400 \mathrm{MHz}$ antenna, the max. interpretable depth reached only 40 ns TWT. Continous reflectors and changing intensities are interpreted as bedding planes, depending on the lithological contrast between soily and conglomeratic sediments. The sedimentary pattern is disturbed and displaced by several reverse and strike-slip faults between the 26 to $37 \mathrm{~m}$ interval. In combination with neotectonic outcrop data (Fig. 5A) we interpret the structure as a positive flower structure developed during transpressive movements along the major fault, probably of a Late Pleistocene ( $>10 \mathrm{ka}$ ) age, probably much older.

\section{3) Playa de Bolmayor site (N $37^{\circ} 05^{\prime} 242, \mathrm{~W} 01^{\circ} 51^{\prime}$ 044)}

The Playa de Bolmayor, north of the Torre del Peñon and south of Mojácar village at the northwestern end of the fault zone (Fig. 2C), was chosen as radar area because of the neotectonic activity described by Bell et al. (1997). The basement of the Alborán Domain is cropping out in two highly deformed and metamorphosed units in the Sierra Cabrera, the structurally deeper Nevado-Filábride Complex and the overthrusting Alpujárride Complex. These units are juxtaposed against Neogene volcanic rocks of the Cabo de Gata Block along the CFZ. Uplifted Tyrrhenian marine terraces (interval III and IV corresponding to 95 - $85 \mathrm{ka}$, Hillaire-Marcel et al., 1986) and Holocene rambla sediments are from the map view obviously neither deformed nor displaced against each other.

We screened a $1,4 \mathrm{~km}$ long section along the beach from the northern most rambla (marked as starting point in Fig. 2C) to the Bar Obscure, where metamorphic rocks are cropping out. A maximum interpretable penetration depth of $75 \mathrm{~ns}$ TWT was obtained applying the $400 \mathrm{MHz}$ antenna. Beside beautiful reflection patterns of rambla sediments (e.g., 


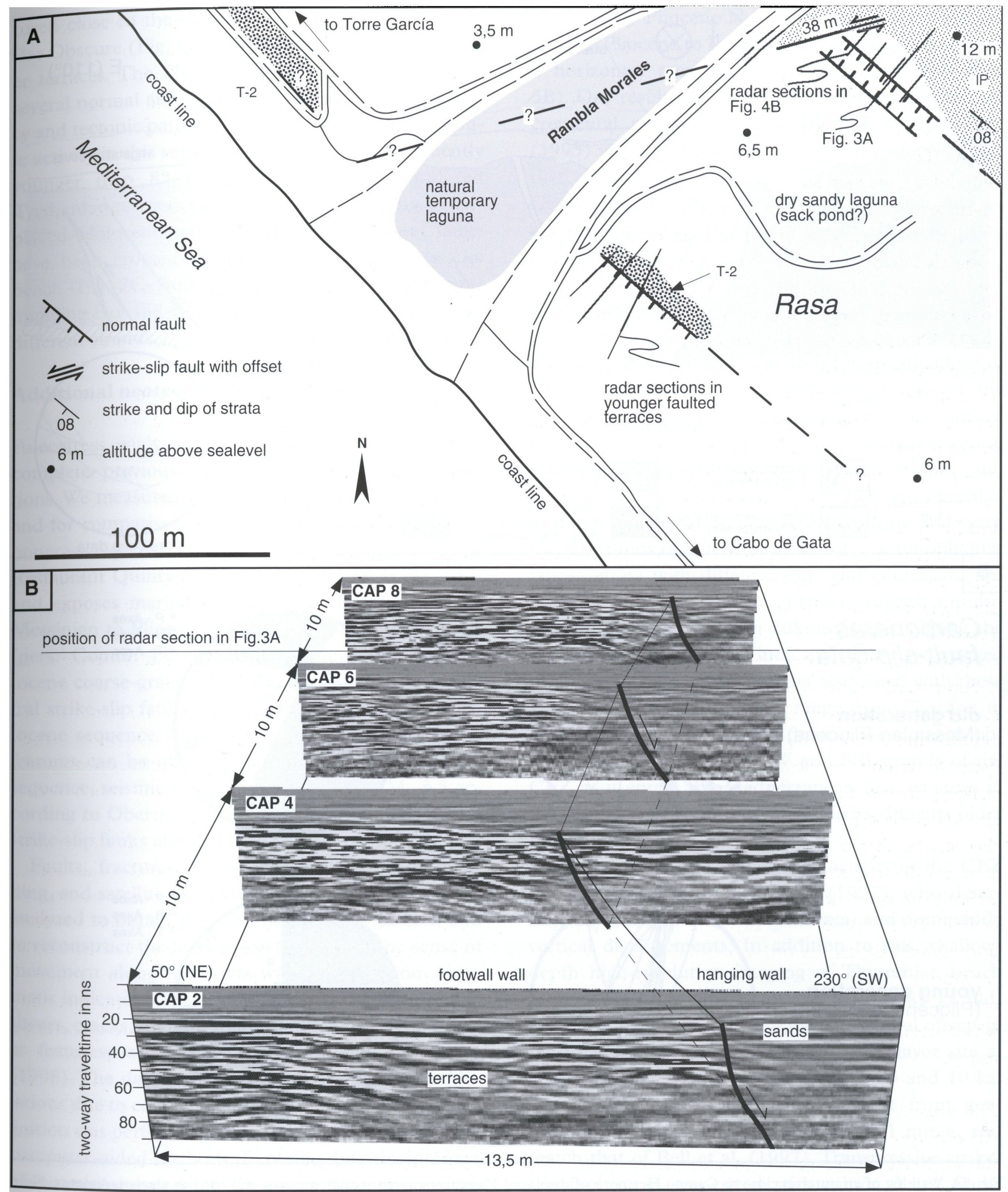

Fig. 4A: Radar locality of the Rambla Morales area near Cabo de Gata (Fig.2A).B: Georadar mapping of the trace and sub-surface expression of the normal fault depicted in Fig. 3A

channeled facies), we detected several fault related sub-surface structures. A little topographic step between Tyrrhenian-3 and 4 terraces and recent rambla sediments close to the starting point (Fig. 2C) turned out to be the expression of faulted terraces juxtaposed to alluvial sediments (sand and gravel). The array of the faults may be interpreted as a 'flower-like' structure, exhibiting both reverse and normal faulting (Fig. 3C). A continous reflector around $42 \mathrm{~ns}$ TWT is due to higher water content, interpreted as sea level, which produces a multiple camouflaging deeper signals (also apparent in Fig. 3D). 


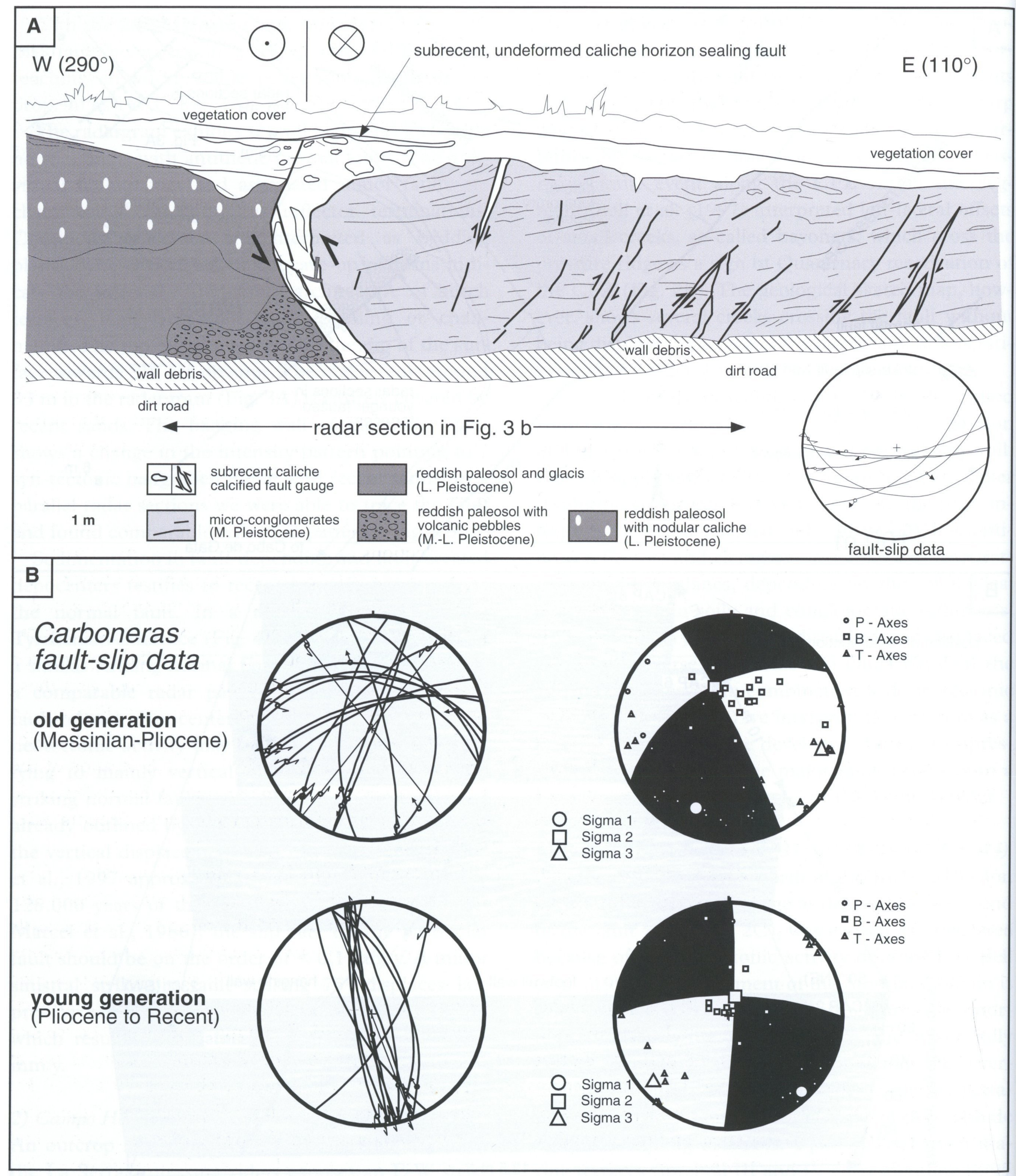

Fig. 5A: Wall log of an outcrop close to Campo Hermoso of displaced Pleistocene micro-conglomerates and reddish glacis sediments. Note several reverse faults associated with the sinistral strike-slip fault. Radar section in Fig. 3B shows subsurface information obtained along the dirt road at the base of the outcrop.

B. Stereographic projection of fault slip-data and paleostress analysis of the outcrop in the Carboneras village, exhibiting two subsequent deformation intervals. Pseudo-fault plane solutions according to fault-slip data (compression = black).

A second example of the Playa de Bolmayor GPR section shows syn-tectonic sedimentary structures and testifies to tectonically induced subsidence in recent coarse-grained sediments. The radar patterns in the hanging wall of a subvertical normal fault show a significant change into concave-up patterns, which are interpreted as faulting-related halfgraben sediments (Fig. 3D). Another strand of the CFZ was cap- 
tured close to the southern end of the beach at the Bar Obscure (Fig. 2C) which displaces Holocene river terraces. The Playa del Bolmayor section yielded several normal and strke-slip fault related sedimentary and tectonic pattern in the radargrams. The tectonic activity in this segment of the CFZ is consequently younger than $85 \mathrm{ka}$, according to the displaced Tyrrhenian terraces III and IV, and according to displaced Holocene terraces sub-recent. Several faults have been crossed by the georadar line across the beach (Fig. 2C, from starting point to Bar Obscure) implying that the CFZ splays from a single fault into different strands.

\section{Additional neotectonic investigations}

Paleostress analysis was carried out in two sites to complete previous studies and georadar investigations. We measured the La Serrata outcrop (Fig. 5A) and for comparison an outcrop in the village of Carboneras (Fig. 5B). The outcrop is located close to the Restaurant Quintana (N $36^{\circ} 59^{\prime} 258$, W $1^{\circ} 54^{\prime} 130$ ) and exposes marine marls and marly limestones of Messinian to Pliocene age with oysters and pectinids (pers. Comm. J.C. Braga), overlain by Plio-Pleistocene coarse-grained colluvial deposits. Major sinistral strike-slip faults cut the entire Pliocene to Pleistocene sequence. Various soft-sediment deformation features can be observed in the Messinian-Pliocene sequence, seismic triggering seems likely $\left(M_{S} 5,5\right.$ according to Obermeier, 1996), induced along sinistral strike-slip faults along the CFZ.

Faults, fractures, joints, slickensides, dip of bedding, and satellite as well as stereoscopic images were analyzed to obtain the local deformation pattern and to reconstruct the local paleostress field. The sense of movement along the faults was deduced from kinematic indicators (Petit, 1987), mainly based on Riedel shears, cracks, fissures, fibrous mineral steps and other features, which have been outlined by Doblas (1998). The data sets required separation into populations due to contradicting slip orientations. The separation was performed by graphical and mathematical computer-aided methods. To obtain the principal axes of the paleostress tensor $\left(\sigma_{1}>\sigma_{2}>\sigma_{3}\right.$; compressional stress) graphical and numerical methods were applied (e.g., Angelier \& Mechler, 1977; Angelier, 1994).

Field and computer-aided separation of paleostress data suggests for the studied outcrop in Carboneras at least a two-phased deformation. Fault directions within the older Messian-Pliocene strata do not appear in the Plio-Pleistocene sequence (Fig. 5B), which gives a relative timing of the faulting. Messin- ian to Early Pliocene N-S compression was followed by Late Pliocene to Recent NW-SE compression with a horizontal maximum shortening direction (Fig. 5B). Our results are in good correlation with the incremental paleostress path observed by Biermann (1995) and Huibregtse et al. (1998), and contradict that of Keller et al. (1995). The fault-slip data of Campo Hermoso (Fig. 5A) document sinistral strikeslip along a secondary fault of the major CFZ during late Pleistocene.

\section{Discussion and Conclusions}

High-resolution imaging due to GPR investigations of Quaternary deposits along different strands of the Carboneras Fault Zone revealed several sub-surface tectonic structures and sediment structures related to active deformation. The studied fault strands and traces as well as associated minor faults are traceable in depth and distance. The faults truncate and warp the reflections of flat-lying sediments, commonly juxtapose strata with different dips and contrasting intensities. Different reflection patterns suggest a multiple faulting history within different sectors along the Carboneras Fault Zone, indicated either by marked faults or syn-tectonic sediments associated with these faults. The studied outcrops range from Pliocene to Holocene age. The youngest deformed sediments observed are located at the SW and NE strands of the CFZ as it enters the Mediterranean Sea, whereas in the central part deformation affected sediments older than $10 \mathrm{ka}$.

Coastal uplift and Quaternary activity of the CFZ has been studied by Bell et al. (1997), who determined low slip rates $(0.05-0.1 \mathrm{~mm} / \mathrm{a})$ and dominantly vertical displacements. In addition to this, shallowdepth high-resolution imaging of Thyrrenian beach terraces (terraces III-IV, approx. 95 and $85 \mathrm{ka}$ old) exhibited both vertical and minor horizontal offsets in the Rambla Morales and Playa del Bolmayor site at least in the latest Pleistocene between 85 and $10 \mathrm{ka}$. The estimates of vertical displacement from georadar-profiling are on the order of $<0.1 \mathrm{~mm} / \mathrm{a}$, and match that of Bell et al. (1997). Transpressive strikeslip faulting is associated with minor thrust faults forming flower structures along the middle segment along the Serrata ridge and the northeastern Playa de Bolmayor segment.

Paleostress data match the present maximum horizontal compression, which is stable since the early Pliocene and NW-SE-directed (Huibregtse et al., 1998). Liqufaction features observed in various outcrops along the CFZ testify to past earthquake activity and hence seismic shaking. Our preliminary results 
suggest a distributed activity of the CFZ during the Late Quaternary, which is also obvious from recent focal mechanisms of the Cabo de Gata Zone. A future target will be to find segment boundaries and arguments for a possible segmentation of the Carboneras Fault Zone.

\section{Acknowledgements}

Financial support of the DFG (German Science Council, Project Re 1361/3-1) is gratefully acknowledged. Thoughtful reviews of two anonymous referees and the help of T. Camelbeeck considerably improved the manuscript.

\section{References}

Alonso-Zarza, A.M., Silva, P.G., Goy, J.L. \& Zazo, C., 1998. Fansurface dynamics and biogenic calcrete development: Interactions during ultimate phases of fan evolution in the semiarid SE Spain (Murcia). Geomorphology 24: 147-167.

Angelier, J., 1994. Fault slip analysis and paleostress reconstruction. In: Hancock, P.L. (ed.), Continental Deformation: 53-100.

Angelier, J. \& Mechler, P., 1977. Sur une méthode graphique de recherche des contraintes principales également utilisable en tectonique et en séismolgie: la méthode des dièdres droits. Bull. Soc. Géol. France 7: 1309-1318.

Biermann, C., 1995. The Betic Cordilleras (SE Spain). Anatomy of a dualistic collision-type orogenic belt. Geol. Mijnbouw 74: 167182.

Bell, J.W., Amelung, F. \& King, G.C.P., 1997. Preliminary late quaternary slip history of the Carboneras fault, southeastern Spain. J. Geodynamics 24: 51-66.

Boorsma, L.J., 1992. Syn-tectonic sedimentation in a Neogene strike-slip basin containing a stacked Gilbert-type delta (SE Spain). Sed. Geol. 81: 105-123.

Boorsma, L.J., 1993. Syn-tectonic sedimentation in a Neogene strike-slip basin (Serrata area, SE Spain). Ph.D. thesis, Univ. of Amsterdam, The Netherlands: $85 \mathrm{pp}$.

Buforn, E., Sanz de Galdeano, C. \& Udias, A., 1995. Seismotectonics of the Ibero-Maghrebian region. Tectonophysics 248: 247-261.

Doblas, M., 1998. Slickenside kinematic indicators. Tectonophysics 295: $187-197$

Hillaire-Marcel, C., Carro, O., Causse, C., Goy, J.L. \& Zazo, C.,
1986. Th/U dating of Strombus bubonius -bearing marine terraces in southeastern Spain. Geology 14: 613-616.

Huibregtse, P., van Alebeek, H., Zaal, M. \& Biermann, C., 1998. Palaeostress analysis of the northern Nijar and southern Vera basins: constraints for Neogene displacement history of major strike-slip faults in the Betic Cordilleras, SE Spain. Tectonophysics 300: 79-101.

Keller, J.V.A., Hall, S.H., Dart, C.J., McClay, K.R., 1995. The geometry and evolution of a transpressional strike-slip system: the Carboneras fault, SE Spain. J. Geol. Soc. London 152: 339. 351.

Keller, J.V.A., Hall, S.H. \& McClay, K.R., 1997. Shear fracture pattern and microstructural evolution in transpressional fault zones from field and laboratory studies. J. Struct. Geol. 19: 1171-1187.

López Marinas, J.L., 1983. El terremoto catastrofico de 22 de Septiembre de 1522, en Almería. Pon. y Comm. Inst. Geogr. Nac. 1: 51-60.

Martin, J.M. \& Braga, J.C., 1995. Tectonic signals in the Messinian stratigraphy of the Sorbas basin (Almeria, SE Spain). In: Friend, P.F. \& Dabrio, C.J. (eds.): Tertiary basins of Spain: 387-391.

Meschede, M., Asprion, U. \& Reicherter, K., 1997. Visualization of tectonic structures in shallow-depth high-resolution groundpenetrating radar (GPR) profiles. Terra Nova 9: 167-170.

Montenat, C. \& Ott D'Estevou, P., 1995. Late Neogene basins evolving in the Eastern Betic transcurrent fault zone: an illustrated review. In: Friend, P.F. \& Dabrio, C.J. (eds.): Tertiary basins of Spain: 372-386.

Obermeier, S.F., 1996. Using Liquefaction-Induced Features for Paleoseismic Analysis. In: McCalpin, J.P. (ed.), Paleoseismology, Int. Geophysics Series, Vol. 62, 331-396 pp.

Petit, J.P., 1987. Criteria for the sense of movement on fault surfaces in brittle rocks. J. Struct. Geol. 9: 597-608.

Sanz de Galdeano, C., 1990. Geologic evolution of the Betic Cordilleras in the western Mediterranean, Micoene to present. Tectonophysics 172: 107-119.

Sanz de Galdeano, C., López-Casado, C., Delgado, J. \& Peinado, M.A., 1995. Shallow seismicity and active faults in the Betic Cordillera. A preliminary approach to seismic sources associated with specific faults. Tectonophysics 248: 293-302.

Seilacher, A., 1969. Fault-graded beds interpreted as seismites. Sedimentology 13: 155-159.

Stapel, G., Moeys, R. \& Biermann, C., 1996. Neogene evolution of the Sorbas basin (SE Spain) determined by paleostress analysis. Tectonophysics 255: 291-305.

Zazo, C., Bardají, T., Dabrio, C.J., Goy, J.L. \& Hillaire-Marcel,C., 1998. Record of Late Pliocene and Quaternary sea-level changes in coastal settings, southeast Spain. IAS Field Trip Guidebook, Alicante 98, Exc. A7: 151-169. 